\title{
TEORI KENABIAN AL-FARABI
}

\author{
Haeruddin \\ Universitas Hasanuddin \\ Email: haeruddin@.unhas.ac.id
}

\begin{abstract}
Abstrak
Penelitian ini memfokuskan pada teori-teori kenabian yang dikembangkan oleh al-farabi. Beliau adalah seorang anak yang menerbitkan ribuan buku yang lengkap. Buku-bukunya banyak mencakupi pembahasan terkait dasar-dasar psikologi, ilmu alam, ilmu akhlak, dan lainlain sebagainya.

Teori kenabian pada masanya banyak dikritisi bahkan oleh pemikir islam sendiri. Bahkan ada yang tidak mengakui konsep kenabian dari berkaitan dengan wahyu yang merupakan perkara gaib. Pembahasan ini mencoba mengkaji teori kenabian yang dikembangkan oleh al-farabi. Teori kenabian Kedudukan Nafsiologi di era sekarang bisa menjadi solusi alternative untuk menjawab beberapa persoalan esensial dalam kehidupan manusia yang selama ini belum mampu terjawab dan diselesaikan secara tuntas oleh psikologi umum.
\end{abstract}

Keywords: Teori; Kenabian; al-Farabi.

\section{Pendahuluan}

Sebutan al-farabi diambil dari nama kota Farab dimana ia dilahirkan pada tahun $257 \mathrm{H}$ $(870 \mathrm{M})$. ayahnya adalah seorang yang bersal dari Iran dan menikah dengan seorang wanita dari Turkestan. Kemudian ia menjadi perwira tentara Turkestan. Karean itu, al-Farabi dikatakan berasal dari keturunan Turkestan dan kadang-kadang juga dikatakan dari keturunan Iran. Nama lengkapnya adalah Abu Nasr Muhamad Bin Muhammad Bin Tarkhan.

Sejak kecilnya Al-Farabi suka belajar dan ia mempunyai kecakapn dalam lapangan bahasa. Bahasa-bahasa yang dikuasainya adalah: bahasa Iran, Turkestan dan Kurdistan. Nampaknya ia tidak mengenal bahasa Yunani dan Siriani, yaitu bahasa-bahasa ilmu pengetahuan dan filsafat pada waktu itu. Setelah besar, Alfarabi meninggalkan negerinya untuk menuju kota Baghdad, pusat pemerintahn dan ilmu pengetahuan pada masanya untuk belajar 
antara lain pada Abu Bisyr Bin Mattius. Selama berada di Bgahdad ia memusatkan perhatiannya kepad ilmu logika.

Nampaknya pada waktu pertama datang di Baghdad, hanya sedikit saja bahasa Arab yang dikuasainya. Ia sendiri mengatakan bahwa ia belajar ilm Nahw (Tata bahasa Arab) pada Abu bakar al-Sarraj, sebagai imbalan atas pelajaran logika yang diberikan oleh al-Farabi kepadanya. Setelah itu ia pindah ka Harran salah satu pusat kebudayaan Yunani di asia Kecil untuk berguru kepada Yohanna Bin Jilan. Tetapi tidak lama kemudian ia kembali meninggalkan kota itu untuk kembali ke Baghdad untuk mendalami ilmu Filsafat setelah menguasai ilmu mantik (logika). Dan di Bghdad ia berdiam selam 30 tahun. Selama waktu itu ia memakai waktunya untuk mengarang dan memberikan pelajaran dan untuk mengulas buku-buku filsafat. Muridnya yang terkenal pada waktu itu ialah Yahya Bin Ady.

Pada tahun 330 Hijriah (941 M), ia pindah ke Damsik, dan disini ia mendapat kedudukan yang baik dari Saifuddaulah salah seorang khalifah dinasti Hamdan di Halab (Aleppo), sehingga ia diajak turut serta dalam suatu pertempuran untuk merebut kota Damsyik, kemudian ia menetap di kota ini sampai wafatnya pada tahun $337 \mathrm{H}$ (950 M) pada usia 80 Tahun.

\section{Kajian Pustaka}

\subsection{Teori Kenabian}

Setiap agama langit tentu mendasarkan ajaran-ajarannya pada wahyu. Seorang nabi tidak lain adalah manusia biasa yang diberi kekuatan untuk dapat berhubungan dengan Tuhan dan menyatakan kehendak-Nya. Agama Islam seperti halnya dengan agama-agama semit, mengambil ajaran-ajarannya dari langit dan sumber-sumbernya yang utama adalah Kitab AlQur'an sebagai wahyu langsung dan Sunnah Nabi sebagai wahyu yang tak langsung. Siapa yang menolak wahyu berarti dia mengingkari Islam keseluruhannya, atau setidak-tidaknya merobohkan sendi-sendi yang utama.

Sebenarnya pengingkaran terhadap wahyu sudah timbul sejak masa Nabi SAW. Orangorang kafir Quraisy tidak mau mengakui bahwa Nabi Muhammad SAW mendapat wahyu dan dapat berhubungan dengan alam ketuhanan, sebab ia adalah manusia biasa yang makan dan minum serta pergi ke pasar (QS.Al-Furqan:7). Setelah al-Qur'an, sebagai mukjizatnya yang membumkan mulut mereka, sedang mereka adalah ahli bahasa dan kesusastraan, maka mereka menuduhnya sebagai tukang sihir. Maka jawaban terhadap tuduhan-tuduhan mereka adalah adalah: "aku ini tidak lain adalah manusia seperti kamu, yang diwahyukan kepadaku” (QS.AlKahf:110) 
Ajaran Islam tentang wahyu mudah dan jelas, dimana malaikat Jibril yang dapat mengambil bermacam-macam bentuk, seperti malaikat lain juga, bertugas sebagai penghubung antara Tuhan dengan nabi-nabi-Nya dan dari Malaikat Jibrillah Muhammad menerima perintah-perintah agamanya, kecuali pada malam Isra' Mi’raj saja. Dimana pada malam itu ia dapat berhubungan secara langsung dengan Tuhan, karena jiwa yang suci pada waktu sedang tidur naik kea lam malakut dan di sana ia melihat rahasia-rahasia alam gaib. Nabi SAW sendiri sebelum memulai dakwahnya taelah melihat impian-impian, sebagai tanda akan dimulainya tugas-tugas, yang di satu surat di dalam al-Qur'an dimana seluruh pembicaraannya berbicara berkisar sekitar impian, yaitu Surat Yusuf, Nabi SAW juga mengatakan tentang impian: "impian yang benar-benar merupakan satu bagian dari 46 tanda kenabian".

\section{Hasil dan Pembahasan}

\subsection{Beberapa Kritik Seputar Kenabian}

Pada masa-masa pertama Islam kaum Muslimin mempercayai sepenuhnya apa yang dating dari Tuhan, tanpa membahasnya atau mencari-cari alasannya. Namun keaadaan ini tidak berlangsung lama karena karena hali ini mulai dikeruhkan dengan oleh berbagai hal keraguan, setelah golongan-golonga di luar Islam perlahan-lahan dapat memasuki fikiran ummat muslim.Golongan-golongan itu adalah golongan Mazdak, dan Manu dari Iran, golongan Sumniyah dari agama Mrahma, serta orang-orang Yahudi dam Masehi. Sejak saat itu, setiap dasar-dasar agama Islam dibahas dan dikritik. Dalam menghadapi kritikna orang-orang yang banyak dari mengkritik tersebut, orang-orang Mu'tazilah telah memberikan bagian yang sukar dicari bandingannya. Sehubungan dengan ini kritikan Ibn ar-Rawandi (Wafat akhir $111 \mathrm{H}$ ) dan Abu Bakar ar-Razi (Wafat $250 \mathrm{H}$ ). terhadap kenabian perlu dicatat.

Ibnu ar-Rawandi dan dalam bukunya yang berjudul Az-Zamarrudah mengingkari kenabian pada umumnya dan kenabian Muhammad SAW pada khususnya, ia banyak membarikan kritikan terhadap ajaran-ajaran Islam dan Ibadahnya, dan menolak mukjizatmukjizat keseluruhannya. Khusus mengenai kenabian, ia mengatakan bahwa rasul-rasul itu sebenarnya tidak diperlukan, karena Tuhan telah memberikan akal kepada manusia, agar mereka dapat membedakan antar yang baik dan yang buruk. Pada intinya Ibnu ar-Rawandi dalam hal ini berpendapat bahwa keberadaan akal itu sudah cukup.

Ar-Razi seorang dokter dan tokoh filsafat, juga tidak kurang bahanya, karena ia menulis dua buku, yaitu: Makhariq al-Anbiya aw Hlya al-Munatanabbi-in (Mainan nabi-nabi atau tipu daya terhadap orang yang mengaku menjadi Nabi) dan Naqdl al-Adyan aw fi an-Nubuwwah (Menentang agama-agama atau tentang kenabian). Menurut Massignon, buku pertama tersebar 
luas, sampai mencapai Dunia Barat, sehingga buku tersebut menjadi sumber kritikan-kritikan yang dlancarkan oleh para rasionalis erofa terhadap agama dan kenabianpada masa Frederick II. Buku kedua, beberapa bagiannya sampai kepada kita melalui tulisan-tulisan Abu Hatim ar-Razi (Wafat tahun $330 \mathrm{H}$ ) dalam bukunya A'lam an-Nubuwwah yang dikarang untuk menolak pandangan ar-Razi mengenai teori kenabian Serangan Abubakar ar-Razi pada garis besarnya pada garis besarnya tidak banyak berbeda dengan serangan ar-Rawandi, seolaholah kedua orang tersebut bersumber satu, atau seolah-olah ajaran Hindu dan Manu tersembunyi di belakangnya, dan tidak jauh kemungkinannya kalau keduanya mengetahui kritik orang-orang Yunani terhadap berbagai agama. Bagaimanapun juga, baik karena terpengaruh oleh fikirannya sendiri, namun yang jelas ialah bahwa ia mengakui dirinya sebagai sebagai orang-orang yang mempunyai kelebihan-kelebihan khusus, baik fikiran maupun rohani, karena semua itu, dan keadilan Tuhan serta hikmah-Nya mengharuskan tidak dibedakannya seseorang dengan lainnya.

\subsection{Pandangan Al-Farabi tentang Kenabian}

Dalam suasana penuh perdebatan tentang kenabian muncullah al-Farabi dan ia merasa bahwa dirinya harus mengambil bagian, apalagi ia hidup semasa dengan Ibnu ar-Rawandi dan Abu Bakar ar-Razi. Sebagai hasil penggabungannya dengan filsafat yang merupakan kegiatan utama bagi filosof-filosof Islam, maka al-Farabi adalah merupakan orang pertama yang membahas tetnag kenabian secara lengkap, sehingga penambahan dari orang lain hampir tidak ada. Total kenabian al-Farabi yang merupakan bagian terpenting dalam filsafat, ditegakkan atas dasar-dasar psikologi dan metafisika, dan erat hubungannya dengan lapangan-lapangan akhlak.

Pada waktu membicarakan negeri utama dari al-Farabi kita melihat bahwa manusia dapat berhubungan dengan akal-faal, meskipun terbatas hanya pada orang tertentu. Hubungan tersebut bisa ditempuh dengan dua jalan, yaitu : jalan fikiran dan jalan imajinasi (penghayalan), atau dengan perkataan lain melalui renungan fikiran dan inspirasi (ilham). Sudah barang tentu tidak semua orang dapat mengadakan hubungan dengan akal faal., melainkan hanya orang yang mempunyai jiwa suci yang dapat menembus dinding-dinding alam gaib dan dapat mencapai alam cahaya. Dengan melalui renungan-renungan fikiran yang banyak, seorang hakim (bijaksana) dapat mengalahkan hubungan tersebut dan orang semacam inilah yang bisa diserahi oleh al-Farabi untuk mengurusi negeri utama yang dikonsepsikannya itu. Akan tetapi di samping melalui pemikiran hubungan dengan akal faal, bisa terjadi dengan jalan imajinasi, dan keadaan ini berlaku bagi nabinabi. Semua ilham dan wahyu yang disampaikan kepada kita merupakan salah satu bekas dan pengaruh imajinasi tersebut. 
Kalau kita kembali kepada pembahasan psikologi dari al-Farabi, maka kita akan mengetahui bahwa imajinasi memainkan peranan yang penting dan memasuki segi-segi gejalagejala psikologis yang bermacam-macam. Imajinasi tersebut erat hubungannya dengan kecondongan dan perasaan, dan ada pengaruhnya pada gerak fikiran dan kemauan, serta mengarahkannya kepada arah tertentu. Di samping ini, imajinasi menyimpan obyek-obyek inderawi dan gambarangambaran alam luar yang masuk kepada otak melalui indera-indera. Malah kadang-kadang tidak hanya menyimpan gambar-gambar fikiran, tetapi juga membuat gambaran baru sama sekali yang tidak ada keserupaaanya dengan obyek-obyek inderawi. Di antara gambarangambaran yang baru sama sekali yang diciptakan oleh imajinasi ialah impianimpian. Dengan demikian maka al-Farabi telah menyebutkan dua macam imajinasi, seperti yang disebutkan oleh sarjana-sarjana psikologi modern, yaitu imagination creatrice (imajinasi pencipta), dan imagination conservatrice (imajinasi penyimpang).

Yang penting dalam hubungannya dengan soal kenabian ialah bagaimana pengaruh imajinasi terhadap impian dan pembentukannya, sebab apabila soal impian ini bisa ditafsirkan secara ilmiah, maka soal kenabian dan lelanjutan-kelanjutannya bisa ditafsirkan pula. Sebagaimana dmaklumi, ilham-ilham kenabian adakalanya terjadi pada waktu tidaur ataupun jaga, atau dengan perkataan lain, dalam bentuk impian yang baenar atau wahyu. Perbedaan antara kedua cara ini bersifat relatif dan hanya mengenai tingkatannya, tetapi tidak mengenai esensinya (hakikatnya). Impian yang benar tidak lain adalh merupakan salah satu cabang kenabian yang erat hubungannya dengan wahyu dan tujuannya juga sama. Meskipun berbeda caranya. Jadi apabila kita dapat menerangkan salah satunya, maka dapat pula kita menerangkan yang lain. Hubungan antara kedua cara tersebut adalah dijelaskan oleh al-Farabi dalam bukunya Ara'u Ahl Madinah al-Fadhilah.

Kalau imajinasi dapat mengadakan gambaran-gambaran tersebut dengan bentuk alam rohani. Misalnya orang tidur melihat langit dan orang-orang yag menempatinya serta meraskan senang terhadap kenikmatan-kenikmatan yang ada di dalamnya. Di samping itu imajinasi kadang-kadang nik kea lam langit dan berhubungan dengan akal-faal untuk menerima hal-hal yang berhubungan dengan peristiwaperistiwa khusus atau peristiwa-peristiwa perorangan, dan dari sini maka terjadilah peramalan tanabbu (peramalan). Hubungan tersebut bisa terjadi di waktu siang atau pun di waktu malam, dan denga adanya hubungan ini mak kita dapat menafsirkan kenabian, karena hubungan tersebut merupakan sumber impian yang benar dan wahyu.

Al-Farabi mengatakan sebagai berikut: 
“jika kekuatan imajinasi pada seseorang kuat sekali, sedangkan obyek-obyek inderawi yang datang padanya dari luar tidak mampu menguasai kekuatan tersebut maka sampai menghabiskan keseluruhannya, dan orang tersebut tidak memakai kekuatan imajinasi itu untuk kekuatan-kekuatan berfikirnya, melainkan di samping mengahdapi kedua pekerjaan tersebut masih ada kelebihan yang banyak dan yang dipakai oleh kekuatan imajinasi untuk menghadapi pekerjaan-pekerjaannya yang khusus, sedang keadaan imajinasi ketika menghadapi kedua pekerjaan tersebut pada waktu jaga, sama dengan keadaan imajinasi ketika terlepas dari jaga yaitu waktu tidur, maka dari kekuatan imajinasi tersebut yang berhubungan dengan kekuatan akal-faal ini, terpantullah gambaran-gambaran yang sangat indah dan sempurna. Orang yang melihat hal sedemikian itu mengatakan bahwa Tuhan mempunyai kebesaran yang agung dan mengagumkan, dan ia melihat perkara-perkara ajaib yang tidak mungkin sama sekali terdapat pada alam maujud. Apabila kekuatan imajinasi seseorang telah mencapai akhir kesempurnaan, maka tidak ada kalangannya pada waktu jaga untuk menerima dari akalfaal peristiwa-peristiwa sekarang atau peristiwa-peristiwa mendatang, atau obyek-obyek inderawi yang merupakan salinannya. Ia dapat pula menerima salinan-salinan dan obyek-obyek fiiran dan wujud-wujud lain yang mulia dan melihatnya pula. Dengan adanya penerimaan-penerimaan itu, maka orang tersebut mempunyai ramalan (Nubuwwah) terhadap perkara-perkara ketuhanan. Ini adalah tingkata yang paling sempurna yang basa dicapai oleh kekuatan imajianasi dan dicapai oleh manusia karena kekuatan tersebut .

Jadi ciri khas pertama seorang nabi menurut al-Farabi, ialah bahwa ia mempunyai daya imajinasi yang kuat dan memungkingkan dia dapat berhubungan dengan akal-faal, baik pada waktu ia tidur maupun pda waktu ia jaga. Dengan imajinasi tersebut ia bisa menerima pengetahuan-pengetahuan dan kebenaran-kebenaran yang Nampak dalam bentuk wahyu dan impian yang benar. Wahyu tidak lain adalah limpahan dari Tuhan melalui akal-faal. Selain nabi nabi-nabi ada orang yang kuat daya imajinasinya, tetapi di bawah tingkatan nabi-nabi, dan oleh karena itu tidak dapat berhubungan dengan akal-faal, kecuali pada waktu tidur, dan kadangkadang mereka sukar untuk dapat mengutarakan apa yang diketahuinya. Adapun orang awam, maka imajinsinya lemah sekali dan tidak sampai berhubungan dengan akalfaal, baik di waktu malam maupun di waktu siang.

Demikianlah teori kenabian kenabian dari al-Farabi yang dipertalikan dengan soal-soal kemasyarakatan, dan kejiwaan, seperti yang dikemukakannya dalam bukunya: Ara- $u$ Ahl al- 
Madinah al-Fadhilah. Menurut al-Farabi, nabi dan filosof adalah orang-orang yang pantas mengepalai negeri utamanya, dimana kedua-duanya dapat berhubungan dengan akal-faal yang menjadi sumber syariat dan aturan yang dperlukan bagi kehidupan tersebut. Perbedaan antara kedua orang tersebut ialah hubungan nabi melalui imajinasi maka hubungan filosof melalui pembahsan dan pemikiran.

\subsection{Beberapa kritik terhadap teori kenabian Al-Farabi}

Jika kita mencoba menganalisis lebih jauh tentang teori kenabian menurut al-Farabi paling tidak ada tiga hal pokok yang menjadi yang bisa kita garis bawahi yaitu:

a. Teori al-Farabi telah menempatkan para nabi di bawah para filosof, karena pengetahuan yang diperoleh telah melalui pemikiran lebih tinggi dari pada yang diperoleh melalui imajinasi.

b. Kalau seorang nabi dapat berhubungan denga akal-faal melalui pemikiran dan renungan, artinya kenabian menjadi semacam ilmu pengetahuan yang memungkinkan setiap orang bisa mencapainya, atau menjadi perkara yang dicari (muktasab), sedang menurut Ahlussunnah kenabian adalah, bukanlah sifat (keadaan) yang bersal dari diri nabi melaingkan, bukan pula tingkatan yang bisa dicapai seseorang melalui ilmu dan usahanya, juga bukanlah kesdiaan psikologis yang memungkinkan dapat berhubungan dengan alam rohani. Melainkan suatu kasih sayang yang diberikan oleh Tuhan kepada orang yang dikehendaki-Nya.

c. Tapsiran psikologis terhadap wahyu banyak berlawanan dengan nas-nas agama Islam, dimana malaikat Jibril turun kepaa nabi SAW dalam bentuk orang atau kadang-kadang terdengar oleh nabi seperti bunyi lonceng, yang sesungguhnya cara turunnya wahyu itu dikenal oleh al-Farabi.

\section{Kesimpulan}

Dari terori kenabian yang dikemukakan oleh Al-Farabi banyak hal;

a. Teori kenabian Kedudukan Nafsiologi di era sekarang bisa menjadi solusi alternative untuk menjawab beberapa persoalan esensial dalam kehidupan manusia yang selama ini belum mampu terjawab dan diselesaikan secara tuntas oleh psikologi umum.

b. Diperlukan sebuah kajian yang lebih dalam lagi untuk bisa menemukan format yang jelas sehingga bisa diterima secara universal di mata dunia

c. Islamisasi ilmu adalah sesuatu yang mutlak adanya untuk mencegah kita dari jalan agama yang cenderung dapat berjalan lancar.

\section{Referensi}

Leanman, Oliver, 1989. Pengantar Filsafat Islam. Jakarta: Rajawali Press. 
Nady Al-Adab | Volume 15 Issue 2 November 2018

Hanafi, Ahmad. 1990. Pengantar Filsafat Islam. Jakarta: Bulan Bintang

Qadir,C.A. 2003. Filasafat dan Ilmu Pengetahuan dalam Islam. Jakarta: Yayasan Obor Indonesia 